OPEN ACCESS

Edited by:

John Love,

University of Exeter, United Kingdom

Reviewed by:

Vinay Kumar

Central University of Punjab, India

Renata Bogatek,

Warsaw University of Life Sciences,

Poland

Roberto Luis Benech-Arnold, University of Buenos Aires, Argentina

${ }^{*}$ Correspondence: Malgorzata M. Posmyk posmyk@biol.uni.lodz.pl

Specialty section: This article was submitted to Plant Metabolism

and Chemodiversity, a section of the journal Frontiers in Plant Science

Received: 22 September 2016 Accepted: 28 August 2017 Published: 14 September 2017

Citation

Kobylińska A, Reiter RJ and Posmyk MM (2017) Melatonin

Protects Cultured Tobacco Cells against Lead-Induced Cell Death via Inhibition of Cytochrome c Translocation

Front. Plant Sci. 8:1560. doi: 10.3389/fpls.2017.01560

\section{Melatonin Protects Cultured Tobacco Cells against Lead-Induced Cell Death via Inhibition of Cytochrome c Translocation}

\author{
Agnieszka Kobylińska ${ }^{1}$, Russel J. Reiter ${ }^{2}$ and Malgorzata M. Posmyk ${ }^{1 *}$ \\ 'Laboratory of Plant Ecophysiology, Faculty of Biology and Environmental Protection, University of Lodz, Lodz, Poland, \\ ${ }^{2}$ Department of Cellular and Structural Biology, UT Health Science Center, San Antonio, TX, United States
}

Melatonin was discovered in plants more than two decades ago and, especially in the last decade, it has captured the interests of plant biologists. Beyond its possible participation in photoperiod processes and its role as a direct free radical scavenger as well as an indirect antioxidant, melatonin is also involved in plant defense strategies/reactions. However, the mechanisms that this indoleamine activates to improve plant stress tolerance still require identification and clarification. In the present report, the ability of exogenous melatonin to protect Nicotiana tabacum L. line Bright Yellow 2 (BY-2) suspension cells against the toxic exposure to lead was examined. Studies related to cell proliferation and viability, DNA fragmentation, possible translocation of cytochrome c from mitochondria to cytosol, cell morphology after fluorescence staining and also the in situ accumulation of superoxide radicals measured via the nitro blue tetrazolium reducing test, were conducted. This work establishes a novel finding by correcting the inhibition of release of mitochondrial ctytocrome $\mathrm{c}$ in to the cytoplasm with the high accumulation of superoxide radicals. The results show that pretreatment with $200 \mathrm{~nm}$ of melatonin protected tobacco cells from DNA damage caused by lead. Melatonin, as an efficacious antioxidant, limited superoxide radical accumulation as well as cytochrome c release thereby, it likely prevents the activation of the cascade of processes leading to cell death. Fluorescence staining with acridine orange and ethidium bromide documented that lead-stressed cells additionally treated with melatonin displayed intact nuclei. The results revealed that melatonin at proper dosage could significantly increase BY-2 cell proliferation and protected them against death. It was proved that melatonin could function as an effective priming agent to promote survival of tobacco cells under harmful lead-induced stress conditions.

Keywords: BY-2 tobacco cells, cytochrome c, DNA fragmentation, melatonin, programmed cell death

\section{INTRODUCTION}

In their natural environment, plants are exposed to many different biotic and abiotic stresses. Among various stressors, heavy metals, especially lead $(\mathrm{Pb})$, are major environmental pollutants, particularly in areas with high anthropogenic pressure (Gill, 2014) and its accumulation has adverse effects on plant growth and crop productivity. $\mathrm{Pb}$ is phytotoxic and found in dust, fumes, mists, 
vapors and in soil as minerals ( $\left.\mathrm{PbCO}, \mathrm{PbS}, \mathrm{PbSO}_{4}\right)$ (Nicholls and Mal, 2003). Although the level of heavy metals in agricultural soil is normally very low, the repeated use of phosphate fertilizers over long periods may cause dangerously high concentrations of some of these toxins (Gill, 2014). Pb is taken up via roots along with water, or it can be absorbed from the air via shoots and foliage (Fahr et al., 2013). Unfortunately, plant roots are not selective and absorb $\mathrm{Pb}$ with other minerals where accumulates. In a number of species, high $\mathrm{Pb}$ levels cause abnormal plant morphology, reduced plant growth and finally it induces cell death (Pourrut et al., 2012). Toxic $\mathrm{Pb}$ concentrations inhibit the activity of key enzymes, e.g., acid phosphatase, esterases, peroxidases, malic dehydrogenase, by reacting with their sulfhydryl groups. Moreover, $\mathrm{Pb}$ contributes to water imbalance, alterations in cell membrane permeability and it limits mineral nutrition. $\mathrm{Pb}$ excess also induces oxidative stress in tissues by increased reactive oxygen species (ROS) generation. Simultaneously, $\mathrm{Pb}$ provokes DNA damage, gene mutations, protein oxidation, lipid peroxidation and finally it promotes signal transduction cascades that promote cell death (Wierzbicka, 1999; Gill, 2014).

Programmed cell death (PCD) is an indispensable process for animals and plant development. In plant systems, PCD falls within two broad categories, environmentally induced and developmentally regulated cell death. Environmentally induced PCD is usually a consequence of external factors including heat shock (Vacca et al., 2006; Lord and Gunawardena, 2012), cold (Lei et al., 2004), pathogen infection leading to a hypersensitivity response (HR) (Mur et al., 2008; Pietrowska et al., 2015) and death caused by heavy metals (Iakimova et al., 2007; Iwase et al., 2014). PCD is an event displayed by many different organisms throughout evolution; however, despite the enormous evolutionary distance across organisms there are some common features including: increased formation of vesicles, cytoplasmic condensation, nuclear condensation, DNA laddering and translocation of cytochrome c (Cyt c) from mitochondria to the cytosol (Isbat et al., 2009; MartínezFábregas et al., 2014). In plant cells, Cyt c release occurs during PCD and is a result of many stimuli such as menadione, D-mannose, heat or ROS (Sun et al., 1999; Stein and Hansen, 1999; Tiwari et al., 2002; Vacca et al., 2004).

Petrosillo et al. (2003) documented that mitochondrialinduced ROS production promotes Cyt $c$ release from mitochondria by a two-step process, including dissociation of Cyt c from cardiolipin, followed by permeabilization of the outer membrane, probably by interaction with voltage dependent anion channels. However, the function of cytoplasmic Cyt c is still controversial since Vacca et al. (2006) found that Cyt $c$ release depended on ROS production, but it may not trigger PCD. Furthermore, after Cyt c translocation, caspase-like proteases inactivate it, leading to Cyt $\mathrm{c}$ degradation en route to PCD (Vacca et al., 2006). However, data of MartínezFábregas et al. (2014) indicated that extra-mitochondrial Cyt $c$ had a double role in causing living cells to die, by triggering the pro-apoptotic routes, e.g., cysteine protease response to dehydration 21 - $\mathrm{RD} 21$, hydroxyacylglutathione hydrolase 2 (GLY2) as well as by inhibiting the pro-survival factors including SET protein (which acts as an inhibitor of p53 acetylation and blocks both p53-mediated cell cycle arrest and apoptosis after stress) or luminal binding protein 1 and 2 (BiP1 and BiP2) whose overexpression increased cell tolerance to endoplasmic reticulum stress as shown in tobacco protoplast (Leborgne-Castel et al., 1999; Martínez-Fábregas et al., 2014).

To reduce the negative impact of various stresses, including $\mathrm{Pb}$ pollution, the best solution may be biostimulators, which improve plant tolerance and protect them against harmful factors. Among many different protective substances naturally occurring in plants, melatonin ( $N$-acetyl-5-methoxytryptamine) seems to have great biostimulatory potential (Janas and Posmyk, 2013). Melatonin has been detected in numerous plant species (Reiter et al., 2015). This indoleamine is a broadspectral antioxidant. It stimulates antioxidant enzymes and synthesis of glutathione, and activates other antioxidants (Bałabusta et al., 2016). It also increases the efficiency of mitochondrial electron transport chain thereby decreasing electron leakage thus limiting free radical generation (Kładna et al., 2003; Rodriguez et al., 2004; Leon et al., 2005; Tan et al., 2007; Reiter et al., 2015; Bałabusta et al., 2016). Moreover, the work of Galano et al. (2013), Tan et al. (2014) and Kołodziejczyk et al. (2015) indicated that the melatonin metabolites, e.g., cyclic-3-hydroxymelatonin, 2-hydroxylmelatonin and especially N1-acetyl-N2-formyl5-methoxykynu-ramine (AFMK) also possessed antioxidant activity. These facts, together with melatonin small size makes it particularly capable of translocating easily between cell compartments and of protecting cell structures against excessive ROS.

Melatonin is also useful to protect plants against heavy metal-induced stresses (Tan et al., 2007). Presowing melatonin treated seeds eliminated the toxic effects of copper ions in Brassica oleracea rubrum during germination (Posmyk et al., 2008) and zinc sulfate in Hordeum vulgare L. roots (Arnao and Hernández-Ruiz, 2009). Relatively little is known about the specific mechanisms of melatonin action at the subcellular level in plants. Lei et al. (2004) showed that pretreatment with melatonin of carrot suspension cells attenuated cell damage caused by cold exposure.

Studying the molecular pathways of PCD in whole plants introduces many difficulties, because it often occurs in a small number of directly stress-affected cells (McCabe and Leaver, 2000). Thus, for analysis of cytotoxic effects, cell lines are of particular suitable. Nicotiana tabacum L. cv Bright Yellow 2 (BY-2) suspension cells are fast growing higher plant cells, which provide an excellent model for examining plant physiology, biochemistry and molecular biology (Nagata et al., 1992). They allow research both at the level of a single cell and in its compartments. The objective of the present study was to determine if pretreatment of a suspension Nicotiana tabacum BY-2 cells with melatonin inhibits $\mathrm{Pb}$-induced PCD. The findings show that melatonin significantly limited the negative effects of this heavy metal and acted as a biostimulating, pro-survival factor. 


\section{MATERIALS AND METHODS}

\section{Plant Material}

Sterile suspensions of in vitro cell cultures of Nicotiana tabacum, L. cv Bright Yellow 2 (BY 2) were used. The cells were cultivated in Linsmaier and Skoog (1965) basal medium (LS) supplemented with $30 \mathrm{~g} \mathrm{l}^{-1}$ sucrose, $0.2 \mathrm{mg} \mathrm{l}^{-1}$ 2,4-dichlorophenoxyacetic acid (2,4-D; synthetic auxin), $1 \mathrm{mg} \mathrm{l}^{-1}$ thiamine, $0.1 \mathrm{~g} \mathrm{l}^{-1}$ myo-inositol and $10^{-2} \mathrm{M} \mathrm{KH}_{2} \mathrm{PO}_{4}$. The initial $\mathrm{pH}$ of the medium was established as 5.3.

\section{Cell Culture and Growth Conditions}

BY-2 suspended cells were routinely propagated and cultured at $25^{\circ} \mathrm{C}$. From the stationary growth phase (day 7 th) of the base culture, $2 \mathrm{ml}$ of cell suspension were passaged into the fresh LS medium as a control (C) and LS with $200 \mathrm{nM}$ melatonin (MEL). The optimal dose of melatonin was chosen experimentally. In the middle of the logarithmic phase of growth (day 4th) $\mathrm{Pb}\left(\mathrm{NO}_{3}\right)_{2}$ was added to LS $(\mathrm{Pb})$ and LS with melatonin $(\mathrm{MEL}+\mathrm{Pb})$ media to the final $\mathrm{Pb}^{2+}$ concentration $15 \mu \mathrm{M}$. Thus, the experiments were performed in four variants: (i) C: BY-2 cells cultured under optimal conditions on LS medium, (ii) MEL: BY-2 cells cultured on LS medium supplemented with melatonin from the start of new culture; (iii) Pb: BY-2 cells cultured on LS medium with $\mathrm{Pb}^{2+}$ added on the 4th day of culture and (iv) MEL $+\mathrm{Pb}: \mathrm{BY}-2$ cells cultured on LS medium with melatonin added from the start of culture and stressed with $\mathrm{Pb}^{2+}$ added on the 4 th day of culture. The cultures were maintained to the 7th day (stationary phase of the control cell growth). The applied concentration of lead was chosen after measurement of $\mathrm{LC}_{50}$ on the $7 \mathrm{th}$ day.

\section{Determination of Cell Growth and Viability}

The cell number was determined with the use of a FuchsRosenthal haemocytometer under a light microscope Olimpus CX-31 equipped with MicroScan v.15. digital system of image analysis; additionally the number of dead cells was assessed after selective staining with methylene blue. Living cells do not take up the stain and retain their natural color whereas damaged cells are stained blue as they are unable to keep the methylene blue from penetrating their membranes. The number of cells and their viability were analyzed every experimental day.

\section{Melatonin Determination}

Melatonin was extracted according to the modified methods of Guerrero et al. (2001) and Hernandez-Ruiz et al. (2004). Its concentration was measured during $\operatorname{lag}, \log$ and the stationary phases of growth. After filtration and separation of the cells from the medium concentrations of melatonin in the extracts were determined using high-performance liquid chromatography (HPLC-MS/MS). For extraction, $5 \mathrm{~g}$ of fresh weight of the cells was homogenized with $5 \mathrm{~mL}$ of $50 \mathrm{mM}$ sodium phosphate buffer ( $\mathrm{pH}$ 8.0) containing $1 \mathrm{mM}$ EDTA and $5 \mu \mathrm{M}$ butylated hydroxytoluene $(\mathrm{BHT})$ as an antioxidant. The homogenate was maintained for $15 \mathrm{~h}$ at room temperature in darkness with minimal shaking, in order to ensure complete extraction of melatonin.

The homogenate was centrifuged at $15000 \mathrm{~g}$ for $10 \mathrm{~min}$ at $5^{\circ} \mathrm{C}$. Initial purification consisted in two steps by solventpartitioning using ethyl acetate and $50 \mathrm{~mm}$ sodium phosphate buffer (first at $\mathrm{pH} 8.0$ and second at $\mathrm{pH} 3.0$ ). The two organic phases were evaporated together under vacuum. Dry residue was re-dissolved in $1 \mathrm{~mL}$ of mobile phase, filtered through Supelco ISO-Disc filters (PTEF-4 - $2.4 \mathrm{~mm} \times 0.2 \mathrm{~m}$; Supelko, Bellefonte, PA, United States), and frozen at $-70^{\circ} \mathrm{C}$ until HPLCMS analysis. The purified extract was subjected to HPLC-MS/MS analysis using an Agilent 1200 LC System coupled with AB Sciex 3200 QTRAP mass detector equipped with TurboSpray Ion Source (ESI). Each sample was injected onto Agilent SB-C18 column.

\section{Assay of Cell Death by Fluorescent Microscopy}

Detection and verification of cell death in the suspension of cells were carried out according to Byczkowska et al. (2013) procedure: (1) $0.5 \mathrm{~mL}$ of the culture medium with $0.5 \mathrm{~mL}$ of the appropriate cell suspension was supplemented with $0.5 \mathrm{~mL}$ of $0.02 \mathrm{M}$ phosphate buffer pH 7.4 (PHB). (2) The cells were stained with the $\mathrm{AO} / \mathrm{EB}$ mixture containing $50 \mu \mathrm{g} \mathrm{cm}^{-3}$ of acridine orange and $50 \mu \mathrm{g} \mathrm{cm}^{-3}$ of ethidium bromide in PHB. (3) Drops of cell suspension were immediately put on glass slides and analyzed for 5 min using fluorescent microscopy with a blue light excitation filter of the Optiphot-2 epi-fluorescence microscope (Nikon) equipped with a camera and Act- 1 software (Precoptic, Poland) for fluorescent microscopy and preparation of microphotographs according to Byczkowska et al. (2013). AO/EB staining included the use of acridine orange which penetrates whole cells and stains the nuclei green and with ethidium bromide which dyes nuclei red and it is only absorbed by damaged cells with impaired cellular and nuclear membrane integrity. From the above data, a curve of the fluorescence intensity of nuclear chromatin after $\mathrm{AO} / \mathrm{EB}$ staining was prepared, as described by Byczkowska et al. (2013). This scale allows the recognition of living, dying and death cells. Living cells have intact nuclei stained green, while dying cells have green-yellow, yellow, yellow-orange, or bright orange nuclei with slightly condensed or fragmented chromatin at the early stage of death whereas with condensed and fragmented chromatin at the late stage. Necrotic cells have structurally normal orange nuclei.

When the color is changed from green to red, values of fluorescence intensity of acridine orange and ethidium bromide increase (Byczkowska et al., 2013).

\section{Cell Fractionation}

Fractionation of cells was performed using the digitonin method according to Ganju and Eastman (2003) with modification of Kobylińska et al. (2006). In all experimental variants the cells were washed twice with PBS and next permeabilized for $30 \mathrm{~min}$ in a buffer containing: $1 \mathrm{mM} \mathrm{NaH} \mathrm{PO}_{4}, 8 \mathrm{mM} \mathrm{Na} \mathrm{HPO}_{4}$, $75 \mathrm{mM} \mathrm{NaCl}, 250 \mathrm{mM}$ sucrose, digitonin ( $0.05 \%$ of cells weight), 
$20 \mu \mathrm{l} / \mathrm{g}$ cells $1 \mathrm{mM}$ phenylmethylsulfonyl fluoride (proteases inhibitor), and cocktail of enzymes for cell wall lysis (CellLytic Sigma). Cell homogenate was obtained by centrifugation at $3000 \mathrm{~g}$ for $1 \mathrm{~min}$. at $4^{\circ} \mathrm{C}$ to remove cell debris. The cleaned homogenate after centrifugation at $12000 \times g$ was divided into two fractions: the supernatant was removed as the cytosolic fraction and the pellet (mitochondrial fraction) was resuspended in the above buffer (without digitonin). To both fractions sufficient volumes of Laemmli sample buffer supplemented with $10 \% \beta$-mercaptoethanol were added (Laemmli, 1970) and the mixtures were boiled for $5 \mathrm{~min}$.

\section{Western Blot Analysis}

Fractionated BY-2 cell lysates (50 $\mu \mathrm{g}$ of proteins) were electrophoretically separated by sodium dodecyl sulfate polyacrylamide gel electrophoresis (SDS-PAGE) on 15\% gel (Laemmli, 1970) and transferred to Immobilon $\mathrm{P}^{S Q}$ at the voltage of $20 \mathrm{~V}$ overnight, at $4^{\circ} \mathrm{C}$ according to Towbin et al. (1979). After blocking in 3\% non-fat dry milk in TBST (10 mM Tris- $\mathrm{HCl}, \mathrm{pH}$ 7.5, $150 \mathrm{mM} \mathrm{NaCl}, 0.05 \%$ Tween-20) for $60 \mathrm{~min}$, the membranes were incubated with primary antibodies specific to Cyt c in TBST in a cold room overnight. Subsequently, the membranes were washed several times in TBST and incubated with appropriate secondary antibodies conjugated with alkaline phosphatase (Sigma Chemical Co.) in TBS for $2 \mathrm{~h}$ at room temperature. Next the membranes were washed several times with TBST, and the proteins were visualized by incubation with the substrate solution $(0.33 \mathrm{mg} / \mathrm{ml}$ of nitro blue tetrazolium, $0.17 \mathrm{mg} / \mathrm{ml}$ of 5-bromo-4-chloro-3-indolyl phosphate in $100 \mathrm{mM}$ Tris- $\mathrm{HCl}, \mathrm{pH}$ 9.5, $100 \mathrm{mM} \mathrm{NaCl}$ and $5 \mathrm{mM} \mathrm{MgCl}_{2}$ ), prepared according to Leary et al. (1983).

\section{DNA Isolation}

DNA digestion was performed using the cetyl-trimethylamonnium bromide (CTAB) method previously described by Murray and Thompson (1980). BY-2 cells from $\log$ phase of growth (4th day, $4 \mathrm{~h}$ after $\mathrm{Pb}^{2+}$ addition) and from the beginning of the stationary phase (6th day, $48 \mathrm{~h}$ after $\mathrm{Pb}^{2+}$ addition) were frozen in liquid nitrogen and ground in a mortar to a fine powder. Then, CTAB buffer (100 mM Tris- $\mathrm{HCl} \mathrm{pH} 8.0,1,4 \mathrm{M}$ $\mathrm{NaCl}, 20 \mathrm{mM}$ EDTA and 2\% CTAB) was added and extraction was performed for $30 \mathrm{~min}$ at $65^{\circ} \mathrm{C}$. After immediate cooling on ice, DNA preparation was continued in the extraction mixture of chloroform/isoamyl alcohol (24:1) until a fine emulsion was created. The organic phase was separated from the aqueous phase by centrifugation at $12000 \times g$ for $15 \mathrm{~min}$ at $4^{\circ} \mathrm{C}$. DNA was precipitated with isopropanol at $-20^{\circ} \mathrm{C}, 20 \mathrm{~min}$. The DNA precipitates were spun at $12000 \times g$ for $10 \mathrm{~min}$ at $4^{\circ} \mathrm{C}$, washed two times in $70 \%$ ethanol and air dried. DNA pellets were dissolved in $100 \mu \mathrm{l}$ TE buffer $(10 \mathrm{mM}$ Tris- $\mathrm{HCl}$ $\mathrm{pH} 7.5$, and $1 \mathrm{mM}$ EDTA) containing $10 \mu \mathrm{l}$ 1\% RNase A. RNA digestion was conducted $2 \mathrm{~h}$ at $37^{\circ} \mathrm{C}$. Purity of the obtained DNA preparations was determined spectrophotometrically by analysis of the absorbance spectra in the range of $230-320 \mathrm{~nm}$. The value of $A_{260 / 280}$ within the limits of 1.8 - 2.0 was the criterion of DNA purity. Then, $5 \mu \mathrm{l}$ of a loading buffer was added to each tube, and the DNA preparations were electrophoresed in 2\% agarose gels and run at $5 \mathrm{~V} / \mathrm{cm}$. The gels were stained with ethidium bromide and visualized under ultraviolet (UV) light.

\section{Statistical Analysis}

The data represent the means \pm standard deviation $( \pm S D)$. Each variant of culture was replicated three times and at least three independent samples were used for measurement. The data were analyzed using STATISTICA v.10.0_MR1_PL [StatSoft] software. One-way or two-way analysis of variance (ANOVA) and then the post hoc Duncan multiple range test was carried out to find the significant differences at $p<0.001$ in each experiment.

\section{RESULTS}

\section{Cell Growth and Viability}

Preincubation with melatonin prior to $\mathrm{Pb}$ treatment protected tobacco suspension cells from death and improved cell proliferation. Cell growth intensity in $\mathrm{C}$ and MEL variants was similar during culture time. After $\mathrm{Pb}$ addition on the 4 th day, a significant inhibition of tobacco cell proliferation was observed (Figure $\mathbf{1 A}$ - see the variants $\mathrm{MEL}+\mathrm{Pb}$ and especially $\mathrm{Pb}$ ). From the first day after heavy metal stress induction, proliferation of the MEL $+\mathrm{Pb}$ cells was about $40 \%$ higher in comparison to those treated with $\mathrm{Pb}$ but not primed with melatonin $(\mathrm{Pb})$ (Figure 1A) this tendency was maintained throughout the duration of the Pb-stress.

The effects of melatonin pretreatment on viability of $\mathrm{Pb}$-stressed tobacco suspension cells were verified in all experimental samples. Methylene blue staining documented the protective effect of melatonin against cell death induced by $\mathrm{Pb}$. The mortality of cells exposed to $\mathrm{Pb}$ but preincubated with melatonin $(\mathrm{MEL}+\mathrm{Pb})$ was slightly higher than in $\mathrm{C}$ and $\mathrm{MEL}$ variants. Culture medium supplementation with melatonin did not result in cell death acceleration. The number of dead cells in the $\mathrm{Pb}$ exposed cells increased significantly and it was 24.2, 37.3 , and $49.2 \%$ for the 1 st, 2 nd, and 3 rd day after $\mathrm{Pb}$ application, respectively (Figure 1B). In contrast, mortality of MEL $+\mathrm{Pb}$ cells was about $80 \%$ lower than in the $\mathrm{Pb}$ cells (Figure 1B).

\section{Detection of Cell Death}

Fluorescence analyses after successive addition of $\mathrm{AO} / \mathrm{EB}$ fluorochromes showed that after $\mathrm{Pb}$ treatment BY-2 cells died via PCD. Yellow and green-yellow nuclei with slightly condensed chromatin dominated among dying cells (Figure 2), but some yellow-stained nuclei with condensed chromatin were also observed. This observation indicates that already $4 \mathrm{~h}$ after $\mathrm{Pb}$ treatment, BY-2 cells underwent the initial stages of cell death. At the end of cell culture (the 7th day; the 3rd day after Pb stress) nuclei with dark orange chromatin were not found, indicating that necrotic type of cell death after $\mathrm{Pb}$ exposure in BY-2 tobacco cells was not detected.

Unexpected effects were obtained for cells exposed to $\mathrm{Pb}$ but pre-incubated with melatonin $(\mathrm{MEL}+\mathrm{Pb})$. The fluorescence intensity of randomly selected nuclei for this treatment was estimated at $16 \%$ and it was similar to the $\mathrm{Pb}$-untreated samples: 

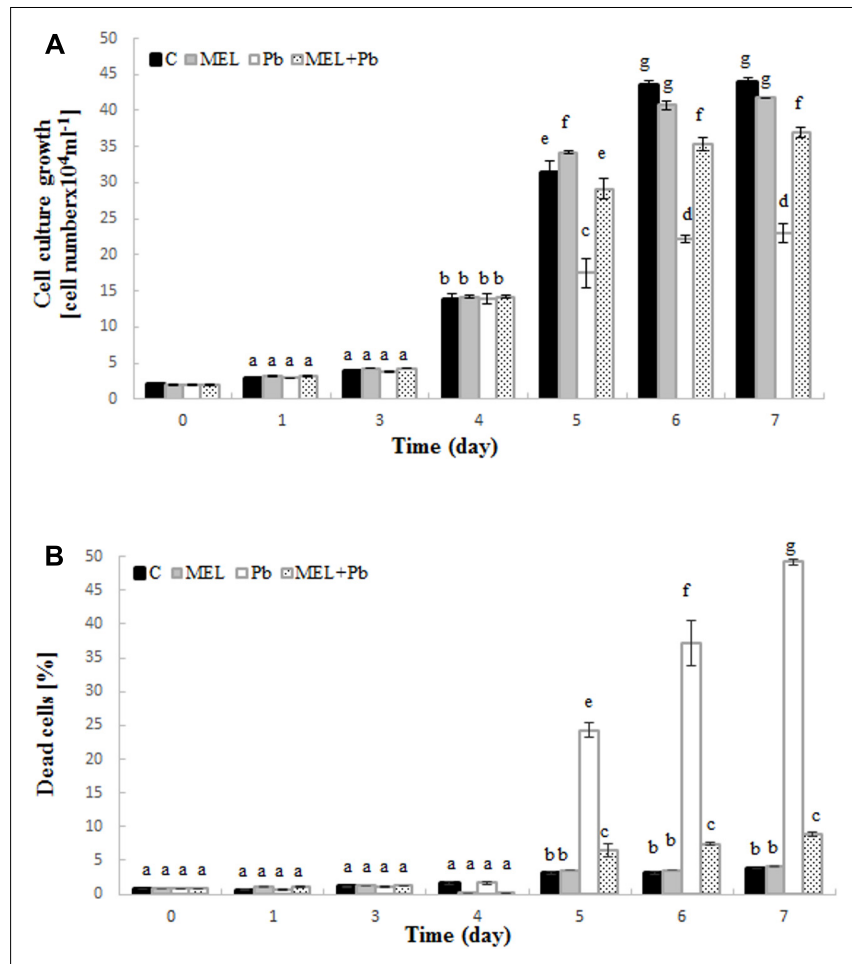

FIGURE 1 | Level of cell growth (A) and mortality (B) of BY-2 tobacco cells in conducted experiments. C, BY-2 cells cultured on LS medium - the control variant; MEL, BY-2 cells cultured on LS medium with $200 \mathrm{nM}$ melatonin added from the beginning of the culture; $\mathrm{Pb}, \mathrm{BY}-2$ cells cultured on LS medium with $15 \mu \mathrm{M} \mathrm{Pb}^{2+}$ added on the 4th day of the culture and MEL $+\mathrm{Pb}, \mathrm{BY}-2$ cells cultured on LS medium with melatonin added from the start of the culture and with $\mathrm{Pb}^{2+}$ added on the 4th day of culture. The results are expressed as mean values of 3 independent experiments \pm SD. Two-way ANOVA and Duncan's post hoc test were performed. The small letters next to the values show statistical significance $p<0.001$. (A) Viability ANOVA results: Variant (C, MEL, Pb, MEL + Pb) $F_{(3 ; 56)}=1189, p<0.0001$; Time $(0,1,3,4,5,6,7)$

$F_{(6 ; 56)}=11505, p<0.0001$; and interaction Variant $\times$ Time $F_{(18 ; 56)}=270$, $p<0.0001$. (B) Mortality ANOVA results: Variant (C, MEL, Pb, MEL + Pb)

$F_{(3 ; 56)}=3207, p<0.0001$; Time $(0,1,3,4,5,6,7) F_{(6 ; 56)}=1637$, $p<0.0001$; and interaction Variant $\times$ Time $F_{(18 ; 56)}=756, p<0.0001$.

14 and $17 \%$ for control and melatonin treated cells respectively. In contrast fluorescence intensity in $\mathrm{Pb}$ variant increased to $53 \%$, and was expressed as yellow/yellow-orange nuclei color (Figure 3).

\section{Profile of DNA Fragmentation}

To gain insight into the mechanism of plant PCD induced by $\mathrm{Pb}$, DNA fragmentation and release of Cyt $\mathrm{c}$ from mitochondria into cytosol was checked. We found an inhibitory effect of melatonin on DNA laddering, one of the hallmarks of PCD. Figure 4 shows that DNA isolated from control and melatonin treated cells remained intact, whereas DNA from $\mathrm{Pb}$ samples exhibits significant fragmentation; this was more intensive $4 \mathrm{~h}$ after $\mathrm{Pb}$ stress then 2 days later (the 6th culture day, the 2nd day after lead treatment). The analyses showed that melatonin completely blocked/reversed the cytotoxic $\mathrm{Pb}$ influence and protected tobacco cells against DNA damage caused by the heavy metal.

\section{Cytochrome c Translocation}

To further confirm the protective action of melatonin, immunodetection of Cyt $\mathrm{c}$ in mitochondrial and cytosolic fractions was examined. There is growing evidence that in plants, as in mammals, translocation of Cyt c from mitochondria to cytosol plays an important role in PCD mediated events. Detection of this protein with an antibody recognizing whole Cyt c molecule was performed in mitochondrial pellet and cytosolic fractions of BY-2 cells in all experimental groups. Unexpected effects were obtained in the 4th hour after $\mathrm{Pb}$ treatment, despite DNA fragmentation at that time, Cyt c was detected only in the mitochondrial pellet, suggesting that Cyt $c$ release from mitochondria to cytosol is a later stage of PCD and takes place independent on DNA damage (Figure 5A). Relatively low, but different levels of Cyt c accumulated in mitochondrial pellet of BY-2 cells in control (C) and melatonin-treated samples (MEL and $\mathrm{MEL}+\mathrm{Pb}$ ) on the 2nd day after $\mathrm{Pb}$ treatment (Figure 5B). Release of Cyt $\mathrm{c}$ from mitochondria into cytosol was observed after $\mathrm{Pb}$ exposure where translocation of Cyt $c$ was accompanied by almost complete disappearance of this protein from the mitochondria and its accumulation in the cytosolic fraction. MEL $+\mathrm{Pb}$ samples were deficient of Cyt c in cytosol, similar to Pb-untreated cells. This cytological and molecular evidence demonstrates that melatonin preincubation protects tobacco suspension cells from $\mathrm{Pb}$-induced PCD.

\section{Content and Cellular Localization of $\mathrm{O}_{2}^{--}$}

To investigate whether the observed a Cyt $c$ release is related to $\mathrm{Pb}$-induced ROS production, we measured in situ accumulation of $\mathrm{O}_{2}^{--}$via the nitro blue tetrazolium reducing (NBT) test. In the non-stressed cells (C, MEL), few formazan precipitants were apparent indicating the physiological origin of ROS. Cytological analyses of $\mathrm{O}_{2}^{-}$production in tobacco suspension cells demonstrated, abundant formazan deposits after $\mathrm{Pb}$ exposure. They were especially visible in the boundary cytoplasm and in nuclei which appeared almost black (Figure 6). In contrast, in the MEL $+\mathrm{Pb}$ samples the amounts of formazan precipitants was similar to that in the control, confirming a reduction in $\mathrm{O}_{2}^{-}$by melatonin.

\section{Melatonin Content in BY-2 Cells}

To test if the protective function of melatonin treatment is related to its uptake from the environment and accumulation in cells, the content of this indoleamine in cell lysates was determined at the main experimental points, i.e., in the lag, $\log$ and stationary phases of growth. Generally, BY-2 tobacco cells have low melatonin levels (Table 1). In the non-melatoninprimed cells ( $\mathrm{C}$ and $\mathrm{Pb}$ ), melatonin increased from zero (the 1st day of culture) to $\sim 1 \mathrm{ng} / \mathrm{g}_{\mathrm{FW}}$ (on the last day). Tobacco suspension cells synthesize endogenous melatonin, but at an extremely low level in comparison with the melatonin-treated cells (MEL and MEL $+\mathrm{Pb}$ ). In addition, in cells under Pb stress the endogenous level of this indoleamine in comparison to the 

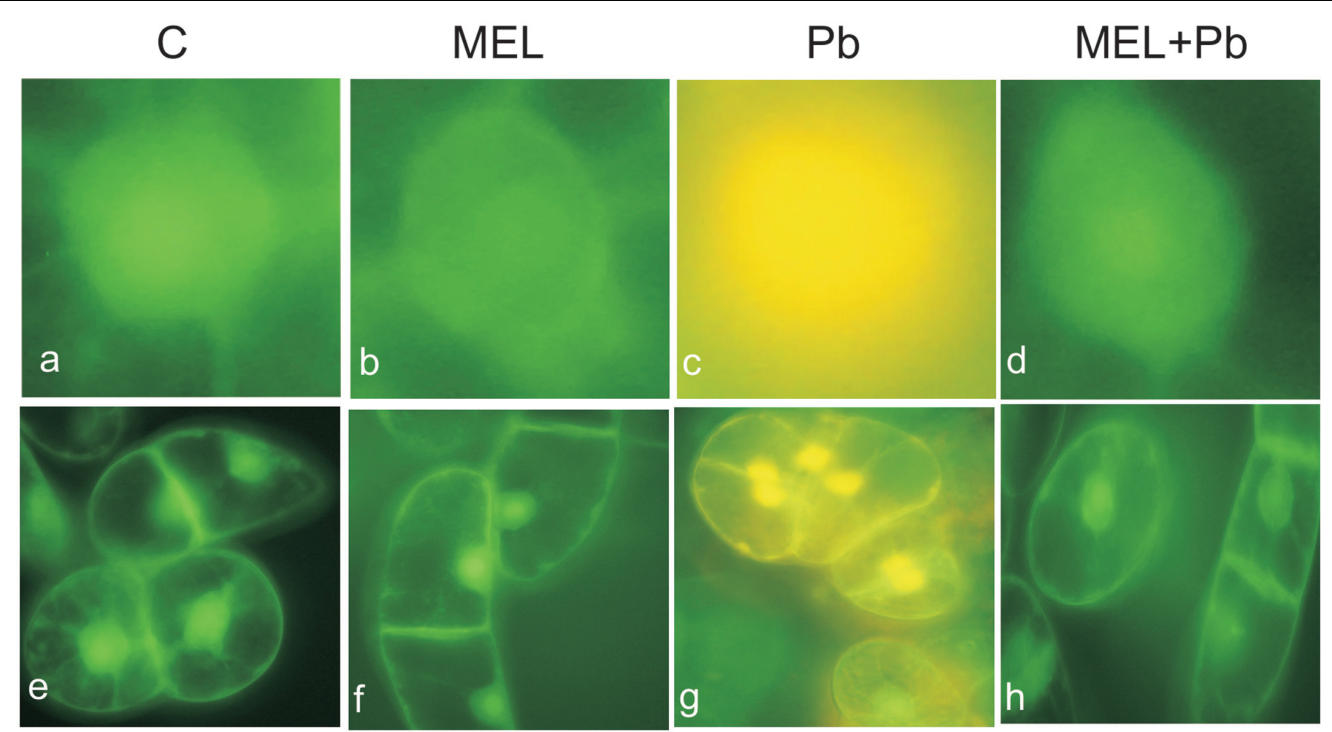

FIGURE 2 | Micrographs of living and dying BY-2 nuclei (a-d) and whole cells (e-h) detected by AO/EB staining. Green nuclei of living cells (a,b,d,e,f,h), yellow nuclei $(\mathbf{c}, \mathbf{g})$ of PCD-dying cells. C, BY-2 cells cultured on LS medium - the control variant; MEL, BY-2 cells cultured on LS medium with 200 nM melatonin added from the beginning of culture; Pb, BY-2 cells cultured on LS medium with $15 \mu \mathrm{M} \mathrm{Pb}{ }^{2+}$ added on the 4th day of culture and MEL + Pb, BY-2 cells cultured on LS medium with melatonin added from the start of the culture and with $\mathrm{Pb}^{2+}$ added on the 4 th day of culture. Micrographs were done $4 \mathrm{~h}$ after lead administration.

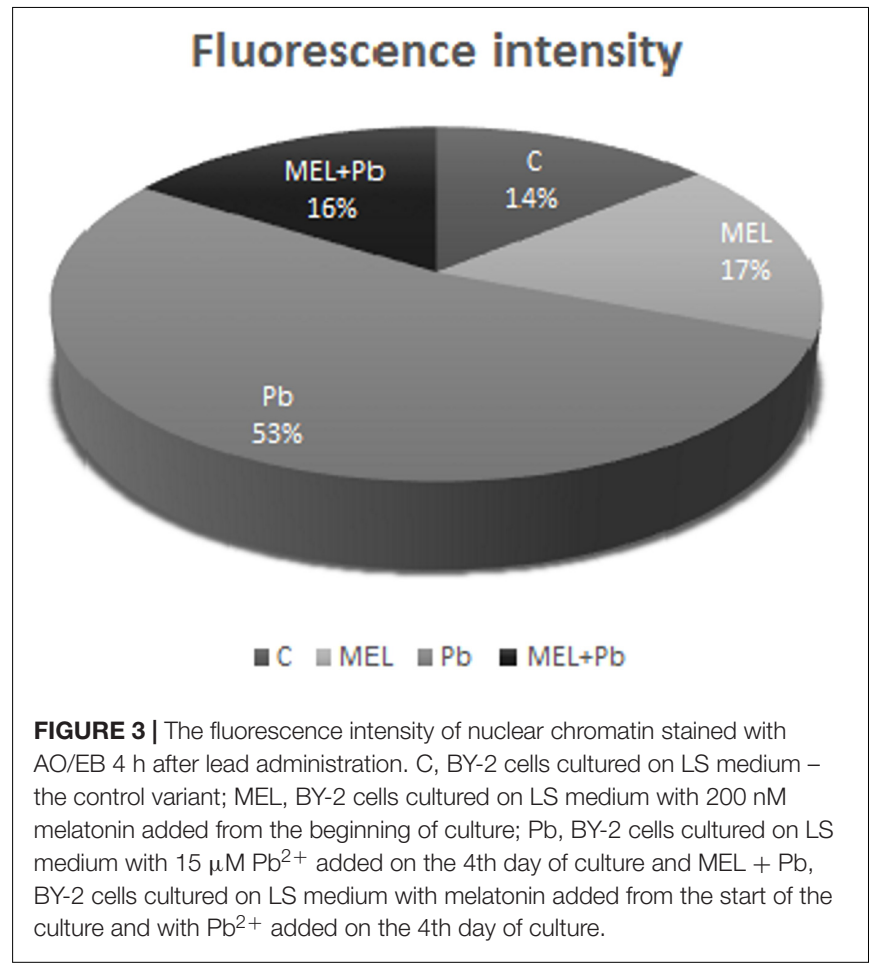

control (C) cells was about $30 \%$ lower at the end of the culture period ( 7 th day). Concentrations of melatonin significantly increased in the cells during the period of melatonin treatment (Table 1). The data indicate that BY-2 cells absorbed melatonin from the medium. Interestingly, MEL $+\mathrm{Pb}$ cells absorbed $20 \%$ more than MEL-treated cells alone.

\section{DISCUSSION}

Melatonin was discovered in the plant kingdom in Dubbels et al. (1995), Hattori et al. (1995) and significant progress has been made in defining its multiple roles in plants. Many researchers underline the fact that among its various roles, its antioxidant effectiveness and free radical scavenging ability, that protect plants against oxidative stress and alleviate or counteract cell damage, are crucial to plant physiology as in animals (Reiter et al., 1997; Tian et al., 2001). Melatonin is widely present in many higher plants (Arnao and Hernandez-Ruiz, 2015; Reiter et al., 2015). Elevated levels of melatonin protect plants against water and soil pollutants by acting as a direct free radical scavenger (Tan et al., 2007; Manchester et al., 2015) and/or as an indirect antioxidant stimulating antioxidant enzymes (Rodriguez et al., 2004; Bałabusta et al., 2016). Melatonin metabolites also posses antioxidant properties and they act in synergy with other antioxidants, such as ascorbic acid, glutathione, etc. (Gitto et al., 2001; Arnao and Hernández-Ruiz, 2009; Kołodziejczyk et al., 2015). Melatonin protects plant tissues and organs, particularly reproductive tissues, fruit and germ tissues of the seeds, from secondary oxidative stress caused by unfavorable environmental conditions, such as drought, salinity, cold, heat, ultraviolet light and ozone (Van Tassel et al., 2001; Dawood and El-Awadi, 2015; Reiter et al., 2015). The data indicate that exogenously applied melatonin also acts as plant biostimulator especially under suboptimal environmental conditions (Posmyk et al., 2008, 2009; Janas and Posmyk, 2013; Kołodziejczyk et al., 2016).

There is growing evidence that in plants melatonin action is associated with its antioxidant properties. Moreover melatonin as the antiapoptotic factor is well documented in various animal cells, but not in plants (Reiter et al., 1997, 2015). Thus, the aim 


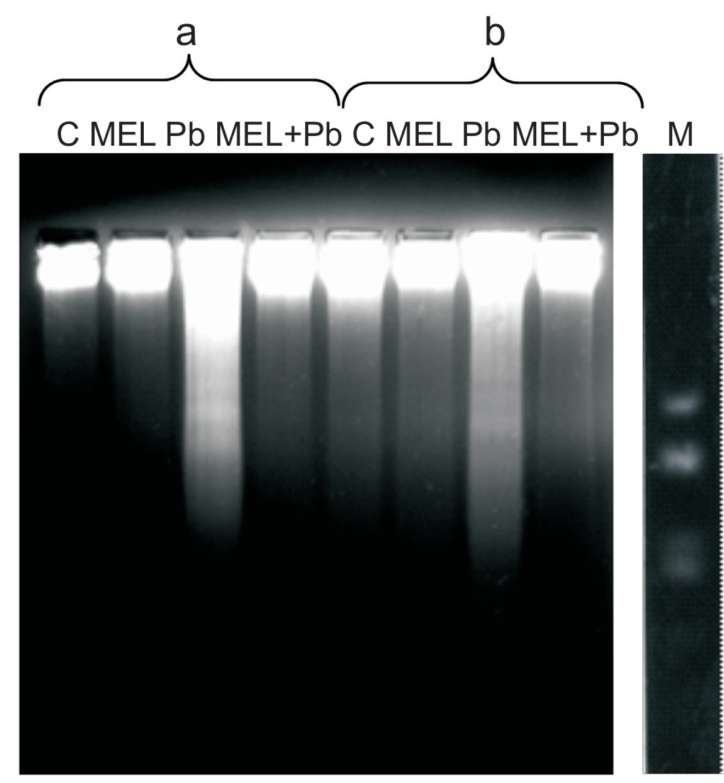

FIGURE 4 | Induction of DNA fragmentation in BY-2 cells exposed to lead. C, BY-2 cells cultured on LS medium - the control variant; MEL, BY-2 cells cultured on LS medium with $200 \mathrm{nM}$ melatonin added from the beginning of the culture; $\mathrm{Pb}, \mathrm{BY}-2$ cells cultured on LS medium with $15 \mu \mathrm{M} \mathrm{Pb}^{2+}$ added on the 4th day of the culture and MEL $+\mathrm{Pb}, \mathrm{BY}-2$ cells cultured on LS medium with melatonin added from the start of the culture and with $\mathrm{Pb}^{2+}$ added on the 4th day of culture. DNA was obtained from the cells: 4 , on the 4th day $-4 \mathrm{~h}$ after lead administration and 6 , on the 6th day -2 days after lead administration. DNA was analyzed by $2 \%$ agarose gel electrophoresis; $M$, molecular weight marker (pUC 18DNA Hae III digest).

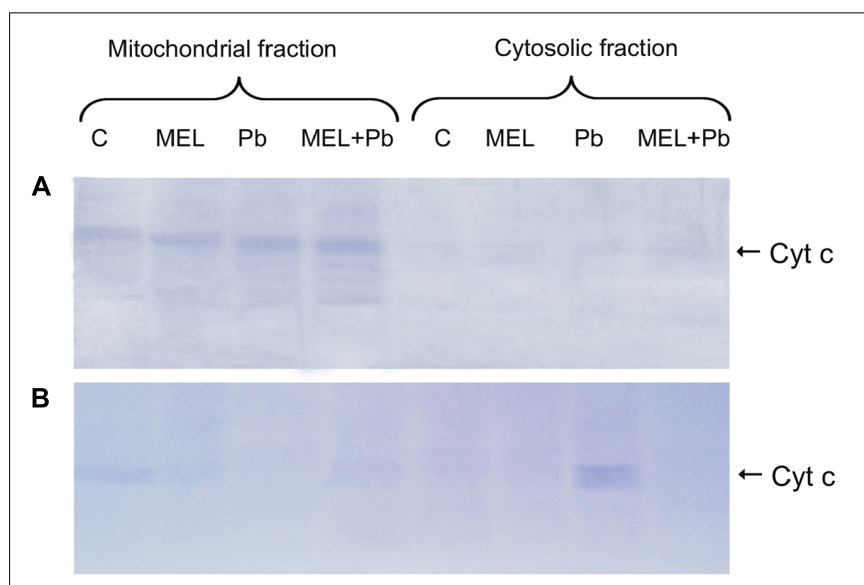

FIGURE $\mathbf{5}$ | Expression of the cytochrome c protein. (A) the 4 th day $-4 \mathrm{~h}$ after lead administration and $\mathbf{( B )}$ the 6 th day -2 days after lead administration. Lysates from untreated BY-2 cells (C), cells grown on the medium supplemented with melatonin (MEL) and cells exposed to lead without and with melatonin treatment ( $\mathrm{Pb}$ and $\mathrm{MEL}+\mathrm{Pb}$, respectively).

of our investigation was to check melatonin influence on heavy metal-induced cell death in tobacco suspension cultures. There is rather little information on the mechanisms by which melatonin prevents plant cells from dying after $\mathrm{Pb}$ exposure.
Presented studies were preceded by analyses of influence the different melatonin concentrations as well as $\mathrm{Pb}$, on BY-2 suspension cells (data not shown). The range of tested melatonin concentrations was $100-1000 \mathrm{nM}$, whereas $\mathrm{Pb} 0.5-50 \mu \mathrm{M}$. The concentration of $\mathrm{Pb}$ applied in presented experiments was chosen on the basis of measurement of LC50 on the 7th day of BY-2 cell cultivation. Our preliminary studies revealed that exogenous melatonin has ambiguous effects on BY-2 cells: it is an effective biostimulator when applied in concentration below $300 \mathrm{nM}$, but in excessive doses (above $300 \mathrm{nM}$ ) it significantly decreased both BY-2 cell proliferation and viability. This agrees with the previous publications of our team, where we also observed different effects of melatonin treatments dependent on the dosage used (Posmyk et al., 2008, 2009; Janas and Posmyk, 2013). This indicates, that melatonin, despite its potentially positive properties (e.g., antioxidative), can not be considered as being always protective since high concentration may have harmful side effects. The choice of dosage is crucial for the positive effects to be realized; in BY- 2 cells melatonin was protective in the range 100-300 nM.

Our preliminary experiments led us to determine the optimal melatonin dose as $200 \mathrm{nM}$ that stimulated proliferation of BY-2 cells and nearly completely reversed effects of $\mathrm{Pb}$ stress. Thus, initially cell proliferation and viability during lag, $\log$ and stationary phases of growth both under optimal ( $\mathrm{C}$ and MEL) as well as under heavy metal stress condition $(\mathrm{Pb}$ and $\mathrm{MEL}+\mathrm{Pb})$ were determined. The positive effects of preincubation of BY-2 cells with melatonin were visible during and after $\mathrm{Pb}$-stress which suggests that melatonin at a concentration $200 \mathrm{nM}$ fortifies cells against potentially stress conditions even before they appear. Proliferation of cells pretreated with melatonin but exposed to $\mathrm{Pb}(\mathrm{MEL}+\mathrm{Pb})$ were only slightly worse than of the unstressed cells ( $C$ and MEL) whereas in the $\mathrm{Pb}$-stressed cells the level of proliferation was more than $50 \%$ lower in comparison to the control. The protective role of melatonin against cell death was clearly visible in the cell mortality analyses during $\mathrm{Pb}$-stress. The number of dead cells in the $\mathrm{Pb}$-treated cells increased drastically while unexpectedly in the MEL $+\mathrm{Pb}$ variant BY-2 cell viability was about $80 \%$ higher than in the $\mathrm{Pb}$ samples (Figure 1B). The melatonin ability to prevent cell death was confirmed by the studies of fluorescence intensity of nuclear chromatin stained with $\mathrm{AO} / \mathrm{EB}$. In our experiments morphological changes in the nuclei of the $\mathrm{Pb}$ exposed cells, i.e., chromatin condensation, green-yellow and yellow color of nuclei, was shown (Figures 2, 3).

Plant cells that undergo PCD exhibit many of the same morphological characteristics as cells undergoing PCD in mammals and Caenorhabditis elegans including intensified formation of vesicles, cytoplasmic condensation, nuclear condensation, DNA fragmentation and chromatin condensation leading to DNA laddering as well as translocation of Cyt c (Balk et al., 2003; Lord and Gunawardena, 2012). Our results showed that in BY-2 cells DNA fragmentation appeared already at $4 \mathrm{~h}$ after $\mathrm{Pb}$ application and it persisted until the 2nd day after $\mathrm{Pb}$ application. In electrophoregrams of DNA samples isolated from the $\mathrm{Pb}$-exposed cells extensive oligonucleosomal 


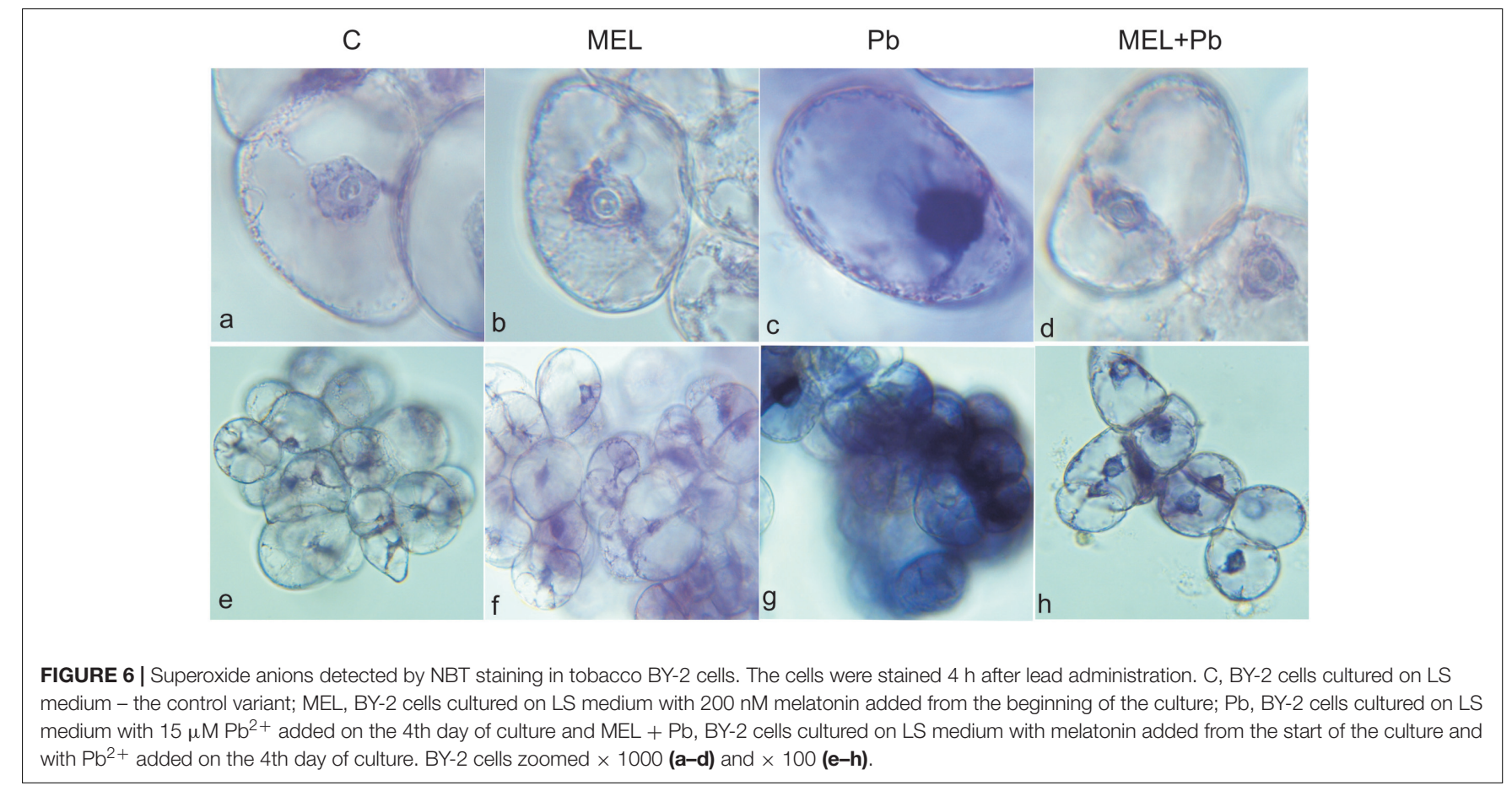

fragmentation caused by this heavy metal was observed, which was not noted in untreated cells (C and MEL). In the MEL $+\mathrm{Pb}$ treated cells melatonin completely blocked DNA laddering. Our results are in line with the studies of Lei et al. (2004) who showed that melatonin increased tolerance to cold in carrot suspension cells and protected their DNA against damage. Similar beneficial effects caused by exogenous melatonin were observed by Posmyk et al. (2008) in red cabbage seedlings subjected to copper stress and in cucumber seedlings subjected to chilling stress (Posmyk et al., 2009).

TABLE 1 | Melatonin concentration (ngMEL/gFW) in homogenates of BY-2 cells in crucial points of conducted experiments.

\begin{tabular}{lccc}
\hline Day of culture $\rightarrow$ Variant & $\mathbf{1}$ & $\mathbf{4}^{\mathbf{1}}$ & $\mathbf{7}$ \\
\hline $\mathrm{C}$ & $0.00 \pm 0.00$ & $0.72 \mathrm{a} \pm 0.01$ & $0.94 \mathrm{a} \pm 0.05^{*}$ \\
$\mathrm{MEL}$ & $6.70 b \pm 0.24$ & $15.18 \mathrm{c} \pm 2.10$ & $34.92 \mathrm{~d} \pm 4.00$ \\
$\mathrm{~Pb}$ & - & - & $0.65 \mathrm{a} \pm 0.24^{* *}$ \\
$\mathrm{MEL}+\mathrm{Pb}$ & - & - & $41.31 \mathrm{e} \pm 3.28$
\end{tabular}

HPLC-MS measurements was performed: 1st day - during lag phase; 4th day after passaging - during log phase, ${ }^{1)}$ this day was also chosen as the start of Pb-stress; and 7th day - during stationary phase of growth (variants $\mathrm{C}$ and MEL) and when Pb-stress symptoms should be detectible (variants $\mathrm{Pb}$ and MEL $+P b)$. Experimental BY-2 cell were cultured according to following variants: control (C) - cells cultured on full LS medium, (MEL) - cell cultured on melatonin-supplemented medium, $(\mathrm{Pb})$ - cells cultured with addition of lead alone and with pretreatment with melatonin (MEL $+P b)$. The results are expressed as mean values of 3-4 measurements \pm SD. Two-way ANOVA and Duncan's post hoc test were performed. The small letters next to the values show statistical significance $p<0.0001$. Melatonin ANOVA results: Variant (C, MEL, Pb, MEL + Pb) $F_{(3 ; 24)}=440, p<0.0001$; Time $(1,4,7) F_{(2 ; 24)}=317, p<0.0001$; and interaction Variant $\times$ Time $F_{(6 ; 24)}=100, p<0.0001$. In a case of $7^{\text {th }}$ day $\mathrm{C}$ and $\mathrm{Pb}$ variant additionally Student's t-test were performed and the statistically significant difference between this two values was determined at $p<0.05$ (marked by stars).
The data presented suggest that pre-incubation of BY-2 cells with melatonin limits the toxicity of $\mathrm{Pb}$ and protects cells against death. We used the plant model system to pinpoint the PCD phase when melatonin may act. It has been reported that release of Cyt $c$ from mitochondrial intermembrane space to cytosol is a conserved pathway of PCD and it has been noted in many systems (Martínez-Fábregas et al., 2013). In plants, this issue has been poorly investigated and the mechanisms of Cyt c release, its role in determining cell death are still controversial. Vacca et al. (2006) reported that heat shock triggered Cyt $\mathrm{c}$ translocation but Cyt $\mathrm{c}$ was degraded en route to cell death. Moreover, Cyt c release is linked to ROS burst and strictly depends on ROS production, and it identifies the early phase of cell death. However, our Western blot analyses did not reveal translocation of Cyt $\mathrm{c}$ from mitochondria to cytosol $4 \mathrm{~h}$ after the heavy metal stress rather this occured much later (the 6th day of culture, the 2nd day after lead administration). Bolduc and Brisson (2002) as well as KawaiYamada et al. (2004) reported that oxidative metabolism leading to generation of ROS was one of the earliest events in PCD induced by biotic or abiotic stress in tobacco plants. Thus, this suggests that high levels of ROS mediate the signaling cascade for defenceive gene induction, e.g., hsp, lea, cor (Vincour and Altman, 2005). In our studies, ROS production and DNA laddering were the early features of PCD and translocation of Cyt c was independent of them. We observed DNA fragmentation before Cyt c translocation, which seems to support the hypothesis of Collazo et al. (2006) that NO/ROS ratio may induce a set of defense responses including cleavage of an inhibitor of caspaseactivated DNAse (ICAD) (Krishnamurthy et al., 2000; Collazo et al., 2006). Although the presence of caspases in plants is debated, cysteine protease activity has been reported to be 
induced in plant systems undergoing cell death (Lam and del Pozo, 2000; Bozhkov et al., 2004). These proteases might function in a plant proteolytic network leading to disconnection of ICAD from DNAse (CAD) and fragmentation of DNA. Moreover, it would confirm our observations that in MEL $+\mathrm{Pb}$ cells, despite $\mathrm{Pb}$ application, DNA was not cleaved since this indoleamine is a highly effective antioxidant and it blocked caspase-like signaling leading to activation of CAD. Furthermore, our results revealed accumulation of superoxide radical in $\mathrm{Pb}$ exposed cells at the 4th hour after $\mathrm{Pb}$ treatment with only a slight detection in the control (C) and melatonin treated cells (MEL, MEL $+\mathrm{Pb}$ ) (Figure 6). Thus, our finding are in line with the data of Vacca et al. (2006) who showed that ROS scavenging inhibited Cyt $c$ release. Jou et al. (2004) documented that in rat brain astrocytes melatonin inhibited opening of mitochondrial permeability transition pore (MPT) and blocked MPT-dependent Cyt c release.

To test whether tobacco cells synthesize endogenous melatonin, and/or are capable of active absorption exogenous melatonin from the environment, the contents of this indoleamine in cell lysates were determined at the crucial points of the experiments, i.e., $\operatorname{lag}, \log$ and stationary phase of growth.

Our results indicated that tobacco BY-2 cells are able to synthesize small amounts of this indoleamine depending on the phase of growth (its endogenous level increased slightly during experiment) as well as to absorb it actively from the medium (Table 1). It is known that biosynthesis and metabolism of this indoleamine are affected and modified by environmental conditions (i.e., stresses), and melatonin levels change during plant ontogenesis (Okazaki and Ezura, 2009). Elevated melatonin synthesis is often combined with the plant defense strategy because generally it was noticed that various plant species rich in melatonin had greater capacity for stress tolerance (Park et al., 2013; Bajwa et al., 2014; Zhang et al., 2015).

Availability of exogenous melatonin allowed BY-2 cells to take up its large quantities throughout the culture period (Table 1). Similar results were observed by Kołodziejczyk et al. (2015) in the case of cucumber and corn seeds which were primed with exogenous melatonin - they absorbed quantities

\section{REFERENCES}

Arnao, M. B., and Hernández-Ruiz, J. (2009). Protective effect of melatonin against chlorophyll degradation during the senescence of barley leaves. J. Pineal Res. 46, 58-63. doi: 10.1111/j.1600-079X.2008.00625.x

Arnao, M. B., and Hernandez-Ruiz, J. (2015). Functions of melatonin in plants: a review. J. Pineal Res. 59, 133-150. doi: 10.1111/jpi. 12253

Bajwa, V. S., Shukla, M. R., and Sherif, S. M. (2014). Role of melatonin in alleviating cold stress in Arabidopsis thaliana. J. Pineal Res. 56, 238-245. doi: 10.1111/jpi. 12115

Bałabusta, M., Szafrańska, K., and Posmyk, M. M. (2016). Exogenous melatonin improves antioxidant defence in cucumber seeds (Cucumis sativus L.) germinated under chilling stress. Front. Plant Sci. 7:575. doi: 10.3389/fpls.2016. 00575

Balk, J., Chew, S. K., Leaver, C. J., and McCabe, P. F. (2003). The intermembrane space of plant mitochondria contains a DNase activity that may be involved in programmed cell death. Plant J. 34, 573-583. doi: 10.1046/j.1365-313X.2003. 01748.x of this indoleamine proportional to its concentration applied during priming (Kołodziejczyk et al., 2015). Interestingly, under unfavorable conditions, $\mathrm{Pb}$-stressed cells $(\mathrm{MEL}+\mathrm{Pb})$ absorbed melatonin near $20 \%$ more intensively in comparison to the unstressed melatonin treated cells (MEL). Although, it is probably not a natural defense strategy of Nicotiana tabacum cells since endogenous melatonin content did not measurably increase in BY-2 cells under $\mathrm{Pb}$ stress conditions (Table 1). These results suggest that BY-2 cells readily absorb and use the accessed exogenous melatonin to counteract stress-induced damage. Survival of plants in polluted environments largely depends on their ability to sequester and/or detoxify toxic substances such as $\mathrm{Pb}$. Tan et al. (2007) also found that melatonin was effective in preventing the death of pea plants grown in soil contaminated with copper.

We have shown that although tobacco is not a plant rich in endogenous melatonin, it is able to use it from an exogenous source as a potential effective factor for improving its stress defenses. This fact once again confirms the practical use of melatonin as a plant biostimulator (Janas and Posmyk, 2013; Kołodziejczyk and Posmyk, 2016; Nawaz et al., 2016). Moreover, we have presented novel findings concerning a decrease of mitochondrial Cyt $c$ release together with limited DNA degradation, which suggest that the protection mechanism of melatonin is not only via limitation of secondary oxidative stress, but also via counteraction against PCD. In conclusion, melatonin has multiple actions as a factor fortifying cells against potential, harmful conditions.

\section{AUTHOR CONTRIBUTIONS}

AK: work conception, all experiments concerning Nicotiana tabacum BY-2 suspension cells realization, data acquisition and analysis, drafting of the manuscript. RR: research consultation/discussion, manuscript revision: language and editorial corrections. MP: methodological consultant, statistical calculations, data analysis and interpretation, manuscript revision.

Bolduc, N., and Brisson, L. F. (2002). Antisense down regulation of NtBI-1 in tobacco BY-2 cells induces accelerated cell death upon carbon starvation. FEBS Lett. 532, 111-114. doi: 10.1016/S0014-5793(02)03650-5

Bozhkov, P. V., Filonova, L. H., Suarez, M. F., Helmersson, A., Smertenko, A. P., Zhivotovsky, B., et al. (2004). VEIDase is a principal caspase-like activity involved in plant programmed cell death and essential for embryonic pattern formation. Cell Death Differ. 11, 175-182. doi: 10.1038/sj.cdd.44 01330

Byczkowska, A., Kunikowska, A., and Kaźmierczak, A. (2013). Determination of ACC-induced cell-programmed death in roots of Vicia faba ssp. minor seedlings by acridine orange and ethidium bromide staining. Protoplasma 250, 121-128. doi: 10.1007/s00709-012-0383-9

Collazo, C., Chacón, O., and Borrás, O. (2006). Programmed cell death in plants resembles apoptosis of animals. Biotecnol. Apl. 23, 1-10.

Dawood, M. G., and El-Awadi, M. E. (2015). Alleviation of salinity stress on Vicia faba 1. Plants via seed priming with melatonin. Acta Biol. Colomb. 20, 223-235.

Dubbels, R., Reiter, R. J., Klenke, E., Goebel, A., Schnakenberg, C., Ehlers, C., et al. (1995). Melatonin in edible plants identified by radioimmunoassay and 
by high performance liquid chromatography-mass spectrometry. J. Pineal Res. 18, 28-31. doi: 10.1111/j.1600-079X.1995.tb00136.x

Fahr, M., Laplaze, L., Bendaou, N., Hocher, V., El Mzibri, M., Bogusz, D., et al. (2013). Effect of lead on root growth. Front. Plant Sci. 4:175. doi: 10.3389/fpls. 2013.00175

Galano, A., Tan, D. X., and Reiter, R. J. (2013). On the free radical scavenging activities of melatonin's metabolites, AFMK and AMK. J. Pineal Res. 54, 245-247. doi: 10.1111/jpi.12010

Ganju, N., and Eastman, A. (2003). Zinc inhibits Bax and Bak activation and cytochrome $\mathrm{c}$ release induced by chemical inducers of apoptosis but not by death-receptor-initiated pathways. Cell Death Differ. 10, 652-661. doi: 10.1038/ sj.cdd. 4401234

Gill, M. (2014). Heavy metal stress in plants: a review. Int. J. Adv. Res. 2, 1043-1055.

Gitto, E., Tan, D. X., Reiter, R. J., Karbownik, M., Manchester, L. C., Cuzzocrea, S., et al. (2001). Individual and synergistic actions of melatonin: studies with vitamin E, vitamin C., glutathione and desferroxamine (desferoxamine) in rat liver homogenates. J. Pharm. Pharmacol. 53, 1393-1401. doi: 10.1211/ 0022357011777747

Guerrero, J. R., Garcia-Ruiz, P., Sanchez-Bravo, J., Acosta, M., and Arnao, M. B. (2001). Quantification of indole-3-acetic acid by LC with electrochemical detection in etiolated hypocotyls of Lupinus albus. J. Liq. Chrom. Rel. Technol. 24, 3095-3104. doi: 10.1081/JLC-100107722

Hattori, A., Migitaka, H., Iigo, M., Itoh, M., Yamamoto, K., Ohtani-Kaneko, R., et al. (1995). Identification of melatonin in plants and its effects on plant melatonin levels and binding to melatonin receptors in vertebrates. Biochem. Mol. Biol. Int. 35, 627-634.

Hernandez-Ruiz, J., Cano, A., and Arnao, M. B. (2004). Melatonin: growthstimulating compound present in lupin tissues. Planta 220, 140-144. doi: 10.1007/s00425-004-1317-3

Iakimova, E. T., Woltering, E. J., and Yordanova, Z. P. (2007). Toxin-and cadmium-induced cell death events in tomato suspension cells resemble features of hypersensitive response. J. Fruit Ornam. Plant Res. 15, 5-19.

Isbat, M., Zeba, N., Kim, S. R., and Hong, C. B. (2009). A BAX inhibitor1 gene in Capsicum annuum is induced under various abiotic stresses and endows multi-tolerance in transgenic tobacco. J. Plant Physiol. 166, 1685-1693. doi: $10.1016 /$ j.jplph.2009.04.017

Iwase, J., Furukawa, H., Hiramaysu, T., Bouteau, F., Mancuso, S., Tanaka, K., et al. (2014). Protection of tobacco cells from oxidative copper toxicity by catalytically active metal-binding DNA oligomers. J. Exp. Bot. 65, 1391-1402. doi: $10.1093 / \mathrm{jxb} / \mathrm{eru} 028$

Janas, K. M., and Posmyk, M. M. (2013). Melatonin, an underestimated natural substance with great potential for agricultural application. Acta Physiol. Plant. 35, 3285-3292. doi: 10.1007/s11738-013-1372-0

Jou, M. J., Peng, T. I, Reiter, R. J., Jou, S. B., Wu, H. Y., and Wen, S. T. (2004). Visualization of the antioxidative effects of melatonin et the mitochondrial level during oxidative stress-induced apoptosis of rat brain astrocytes. J. Pineal Res. 32, 55-60. doi: 10.1111/j.1600-079X.2004.00140.x

Kawai-Yamada, M., Ohmori, Y., and Uchimiya, H. (2004). Dissection of Arabidopsis Bax inhibitor-1 suppressing Bax-, hydrogen peroxide-, and salicylic acid-induced cell death. Plant Cell 16, 21-32. doi: 10.1105/tpc.014613

Kładna, A., Aboul-Enien, H. Y., and Kruk, I. (2003). Enhancing effect of melatonin on chemiluminescence accompanying decomposition of hydrogen peroxide in the presence of copper. Free Radic. Biol. Med. 12, 1544-1554. doi: 10.1016/ S0891-5849(03)00180-1

Kobylińska, A., Bednarek, J., Blonski, J. Z., Hanausek, M., Walaszek, Z., Robak, T., et al. (2006). In vitro sensitivity of B-cell chronic lymphocytic leukemia to cladribine and its combinations with mafosfamide and/or mitoxantrone. Oncol. Rep. 16, 1389-1395. doi: 10.3892/or.16.6.1389

Kołodziejczyk, I., Bałabusta, M., Szewczyk, R., and Posmyk, M. M. (2015). The levels of melatonin and its metabolites in conditioned corn (Zea mays L.) and cucumber (Cucumis sativus L.) seeds during storage. Acta Physiol. Plant. 37, 105. doi: 10.1007/s11738-015-1850-7

Kołodziejczyk, I., Dzitko, K., Szewczyk, R., and Posmyk, M. M. (2016). Exogenous melatonin improves corn (Zea mays L.) embryo proteome in seeds subjected to chilling stress. J. Plant Physiol. 193, 47-56. doi: 10.1016/j.jplph.2016. 01.012

Kołodziejczyk, I., and Posmyk, M. M. (2016). Melatonin - a new plant biostimulator? J. Elem. 21, 1187-1198. doi: 10.5601/jelem.2015.20.3.1012
Krishnamurthy, K. V., Krishnaraj, R., Chozhavendan, R., and Christopher, F. S. (2000). The programmed of cell death in plants and animals. A comparison. Curr. Sci. 79, 1169-1181.

Laemmli, U. K. (1970). Cleavage of structural proteins during the assembly of the head of bacteriophage T4. Nature 227, 680-685. doi: 10.1038/227680a0

Lam, E., and del Pozo, O. (2000). Caspase-like protease involvement in the control of plant cell death. Plant Mol. Biol. 44, 417-428. doi: 10.1023/A:1026509012695

Leary, J. J., Brigati, J. J., and Ward, D. C. (1983). Rapid biotin labelled DNA probes hybrized to DNA or RNA immobilized on nitrocellulose: Bio-blots. Proc. Natl. Acad. Sci. U.S.A. 80, 4045-4049. doi: 10.1073/pnas.80.13.4045

Leborgne-Castel, N., Jelitto-Van Dooren, E. P., Crofts, A. J., and Denecke, J. (1999). Overexpression of $\mathrm{BiP}$ in tobacco alleviates endoplasmic reticulum stress. Plant Cell 11, 459-470. doi: 10.1105/tpc.11.3.459

Lei, X. Y., Zhu, R. Y., Zhang, G.-Y., and Dai, Y.-R. (2004). Attenuation of coldinduced apoptosis by exogenous melatonin in carrot suspension cells: the possible involvement of polyamines. J. Pineal Res. 36, 126-131. doi: 10.1046/ j.1600-079X.2003.00106.x

Leon, J., Acuna-Castroviejo, D., Escames, G., Tan, D. X., and Reiter, R. J. (2005). Melatonin mitigates mitochondrial malfunction. J. Pineal Res. 38, 1-9. doi: 10.1111/j.1600-079X.2004.00181.x

Linsmaier, E. M., and Skoog, F. (1965). Organic growth factor requirements of tobacco tissue 387 cultures. Physiol. Plant. 18, 100-127. doi: 10.1111/j.13993054.1965.tb06874.x

Lord, C. E., and Gunawardena, A. H. (2012). Programmed cell death in C. elegans, mammals and plants. Eur. J. Cell Biol. 91, 603-613. doi: 10.1016/j.ejcb.2012. 02.002

Manchester, L. C., Coto-Montes, A., Boga, J. A., Anderson, L. P., Zhou, Z., Galano, A., et al. (2015). Melatonin: an ancient molecule that makes oxygen metabolically tolerable. J Pineal Res. 59, 403-419. doi: 10.1111/jpi.12267

Martínez-Fábregas, J., Diaz-Moreno, I., Gonzalez-Arzola, K., Janocha, S., Navarro, J. A., Hervás, M., et al. (2013). New Arabidopsis thaliana cytochrome c partners: a look into the elusive role of cytochrome $\mathrm{c}$ in programmed cell death in plants. Moll. Cell Prot. 12, 3666-3676. doi: 10.1074/mcp.M113.030692

Martínez-Fábregas, J., Díaz-Moreno, I., González-Arzola, K., Janocha, S., Navarro, J. A., Hervás, M., et al. (2014). Structural and functional analysis of novel human cytochrome C targets in apoptosis. Mol. Cell Proteomics 13, 1439-1456. doi: 10.1074/mcp.M113.034322

McCabe, P. F., and Leaver, C. J. (2000). Programmed cell death in cell cultures. Plant Mol. Biol. 44, 359-368. doi: 10.1023/A:1026500810877

Mur, L. A. J., Kenton, P., Lloyd, A. J., Ougham, H., and Prats, E. (2008). The hypersensitive response; the centenary is upon us but how much do we know? J. Exp. Bot. 59, 501-520. doi: 10.1093/jxb/erm239

Murray, M. G., and Thompson, W. F. (1980). Rapid isolation of high molecular weight plant DNA. Nucleic Acids Res. 8, 4321-4326. doi: 10.1093/nar/8.19.4321

Nagata, T., Nemoto, Y., and Hasezawa, S. (1992). Tobacco BY-2 cell line as the "HeLa" cell in the 385 cell biology of higher plants. Int. Rev. Cytol. 132, 1-30. doi: $10.1016 / \mathrm{S} 0074-7696(08) 62452-3$

Nawaz, M. A., Huang, Y., Bie, Z., Ahmed, W., Reiter, R. J., Niu, M., et al. (2016). Melatonin: current status and future perspectives in plant science. Front. Plant Sci. 6:1230. doi: 10.3389/fpls.2015.01230

Nicholls, M. A., and Mal, T. K. (2003). Effects of lead and copper exposure on growth of an invasive weed, Lythrum salicaria L. (Purple Loosestrife). Ohio J. Sci. 103, 129-133.

Okazaki, M., and Ezura, H. (2009). Profiling of melatonin in the model tomato (Solanum lycopersicum L.) cultivar Micro-Tom. J. Pineal Res. 46, 338-343. doi: 10.1111/j.1600-079X.2009.00668.x

Park, S., Lee, D. E., Jang, H., Byeon, Y., Kim, Y. S., and Back, K. (2013). Melatonin rich transgenic rice plants exhibit resistance to herbicide-induced oxidative stress. J. Pineal Res. 54, 258-263. doi: 10.1111/j.1600-079X.2012.01029.x

Petrosillo, G., Ruggiero, F. M., and Paradies, G. (2003). Role of reactive oxygen species and cardiolipin in the release of cytochrome $c$ from mitochondria. FASEB J. 17, 2202-2208. doi: 10.1096/fj.03-0012com

Pietrowska, E., Różalska, S., Kaźmierczak, A., Nawrocka, J., and Małolepsza, U. (2015). Reactive oxygen and nitrogen (ROS and RNS) species generation and cell death in tomato suspension cultures-Botrytis cinerea interaction. Protoplasma 252, 307-319. doi: 10.1007/s00709-014-0680-6

Posmyk, M. M., Bałabusta, M., Wieczorek, M., Sliwinska, E., and Janas, K. M. (2009). Melatonin applied to cucumber (Cucumis sativus L) seeds improves 
germination during chilling stress. J. Pineal Res. 46, 214-223. doi: 10.1111/j. 1600-079X.2008.00652.x

Posmyk, M. M., Kuran, H., Marciniak, K., and Janas, K. M. (2008). Presowing seed treatment with melatonin protects red cabbage seedlings against toxic copper concentrations. J. Pineal Res. 45, 24-31. doi: 10.1111/j.1600-079X.2007.00552.x

Pourrut, B., Shahid, M., Dumat, C., Winterton, P., and Pinelli, E. (2012). Lead uptake, toxicity, and detoxication in plants. J. Plant Physiol. 213, 113-136. doi: 10.1007/978-1-4419-9860-6-4

Reiter, R. J., Tan, D. X., Zhou, Z., Cruz, M. H., Fuentes-Broto, L., and Galano, A. (2015). Phytomelatonin: assisting plants to survive and thrive. Molecules 20, 7396-7437. doi: 10.3390/molecules20047396

Reiter, R. J., Tang, L., Garcia, J. J., and Muñoz-Hoyos, A. (1997). Pharmacological actions of melatonin in free radical pathophysiology. Life Sci. 60, 2255-2271. doi: 10.1016/S0024-3205(97)00030-1

Rodriguez, C., Mayo, J. C., Sainz, R. M., Antolín, I., Herrera, F., Martín, V., et al. (2004). Regulation of antioxidant enzymes: a significant role for melatonin. J. Pineal Res. 36, 1-9. doi: 10.1046/j.1600-079X.2003.00092.x

Stein, J. C., and Hansen, G. (1999). Mannose induces an endonuclease responsible for DNA laddering in plant cells. Plant Physiol. 121, 71-80. doi: 10.1104/pp.12 1.1.71

Sun, Y., Zhao, Y., Hong, X., and Zhai, Z. (1999). Cytochrome c release and caspase activation during menadione - induced apoptosis in plants. FEBS Lett. 462, 317-332. doi: 10.1016/S0014-5793(99)01539-2

Tan, D. X., Hardeland, R., Manchester, L. C., Galano, A., and Reiter, R. J. (2014). Cyclic-3-hydroxymelatonin (C3HOM), a potent antioxidant, scavenges free radicals and suppresses oxidative reactions. Curr. Med. Chem. 21, 1557-1565. doi: 10.2174/0929867321666131129113146

Tan, D. X., Manchester, L. C., Helton, P., and Reiter, R. J. (2007). Phytoremediative capacity of plants enriched with melatonin. Plant Signal. Behav. 2, 514-516. doi: $10.4161 /$ psb.2.6.4639

Tian, Y. M., Li, P. P., Jiang, X. F., Zhang, G. Y., and Dai, Y. R. (2001). Rejuvenation of degenerative thymus by oral melatonin administration and the antagonistic action of melatonin against hydroxyl radical-induced apoptosis of cultured thymocytes in mice. J. Pineal Res. 31, 214-221. doi: 10.1034/j.1600-079X.2001. 310304.x

Tiwari, B. S., Belenghi, B., and Levine, A. (2002). Oxidative stress increased respiration and generation of reactive oxygen species, resulting in ATP depletion, opening of mitochondrial permeability transition, and programmed cell death. Plant Physiol. 128, 1271-1281. doi: 10.1104/pp.010999

Towbin, H., Staechlin, T., and Gordon, J. (1979). Electrophoretic transfer of protein from polyacrylamide gels to nitrocellulose sheets: procedure and some applications. Proc. Natl. Acad. Sci. U.S.A. 76, 4350-4354. doi: 10.1073/pnas.76. 9.4350

Vacca, R. A., de Pinto, M. C., Valenti, D., Passarella, S., Marra, E., and De Gara, L. (2004). Production of reactive oxygen species, alteration of cytosolic ascorbate peroxidase, and impairment of mitochondrial metabolism are early events in heat shock-induced programmed cell death in tobacco Bright-Yellow 2 cells. Plant Physiol. 134, 1100-1112. doi: 10.1104/pp.103. 035956

Vacca, R. A., Valenti, D., Bobba, A., Merafina, R. S., Passarella, S., and Marra, E. (2006). Cytochrome $c$ is released in a reactive oxygen species-dependent manner and is degraded via caspase-like proteases in Tobacco Bright-Yellow 2 cells en route to heat shock-induced cell death. Plant Physiol. 141, 208-219. doi: 10.1104/pp.106.078683

Van Tassel, D. L., Roberts, N., Lewy, A., and O’Neill, S. D. (2001). Melatonin in plant organs. J. Pineal Res. 31, 8-15. doi: 10.1034/j.1600-079X.2001.310102.x

Vincour, B., and Altman, A. (2005). Recent advances in engineering plant tolerance to abiotic stress: achievements and limitations. Curr. Opin. Biotechnol. 16, 123-132. doi: 10.1016/j.copbio.2005.02.001

Wierzbicka, M. (1999). The effect of lead on the cell cycle in the root meristem of Allium cepa L. Protoplasma 207, 186-194. doi: 10.1007/BF01282999

Zhang, N., Sun, Q., and Zhang, H. (2015). Roles of melatonin in abiotic stress resistance in plants. J. Exp. Bot. 66, 647-656. doi: 10.1093/jxb/eru336

Conflict of Interest Statement: The authors declare that the research was conducted in the absence of any commercial or financial relationships that could be construed as a potential conflict of interest.

Copyright (C) 2017 Kobylinska, Reiter and Posmyk. This is an open-access article distributed under the terms of the Creative Commons Attribution License (CC BY). The use, distribution or reproduction in other forums is permitted, provided the original author(s) or licensor are credited and that the original publication in this journal is cited, in accordance with accepted academic practice. No use, distribution or reproduction is permitted which does not comply with these terms. 